\title{
MIEJSCE WILNA W IDEOLOGII PRZEDWOJENNEGO NACJONALIZMU LITEWSKIEGO
}

Dangiras Mačiulis \& Darius Staliūnas, Lithuanian nationalism and the Vilnius question 1883-1940. Marburg 2015: Verlag Herder-Institut. (Studien zur Ostmitteleuropaforschung, 32), ss. 236.

\section{THE PLACE OF VILNUS IN THE IDEOLOGY OF PRE-WAR LITHUANIAN NATIONALISM}

\begin{abstract}
The text is a critical review of the book authored by Dangiras Mačiulis and Darius Staliūnas, entitled Lithuanian nationalism and the Vilnius question 1883-1940. The book was published in 2015 by the Herder Institute in Marbourg, Germany. The author of this review presents the contents of this publication and analyses the attitude of Lithuanian historians towards the title question. In particular, the sources of the Lithuanian nationalism and Polish-Lithuanian-Belarusian approach to Vilnus are discussed in the review. [Trans. by Jacek Serwański]
\end{abstract}

Key words: nationalism; Vilnus; Lithuania; history

Streszczenie

Tekst jest krytycznym omówieniem wydanej w 2015 roku przez Instytut Herdera w Marburgu książki Dangirasa Mačiulisa i Dariusa Staliūnasa zatytułowanej Lithuanian nationalism and the Vilnius question 1883-1940. Autor recenzji prezentuje zawartość wydawnictwa oraz analizuje jego treść i omawia

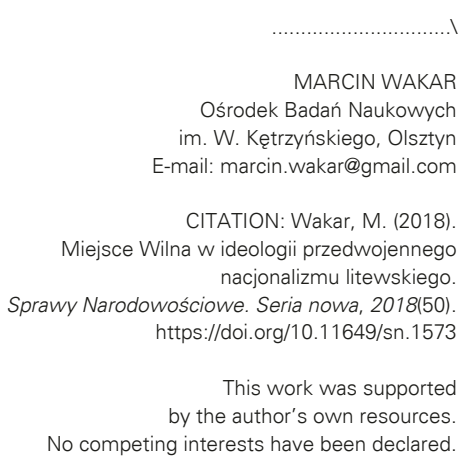

This is an Open Access article distributed under the terms of the Creative Commons Attribution 3.0 PL License (creativecommons.org/licenses/by/3.0/pl/), which permits redistribution, commercial and non-commercial, provided that the article is properly cited. (C) The Author(s) 2018.

Publisher: Institute of Slavic Studies, Polish Academy of Sciences 
wykorzystaną przez litewskich historyków bibliografię. Omawia też źródła litewskiego nacjonalizmu i polsko-litewsko-białoruski spór o Wilno.

Stowa kluczowe: nacjonalizm; Wilno; Litwa; historia

$\mathrm{N}$ ie od dziś zadawałem sobie pytanie o źródła litewskiego nacjonalizmu i polskolitewsko-białoruski spór o Wilno. Miasto, tak ważne dla tych narodów, jest dziś stolicą niepodległej Republiki Litewskiej. Na pytanie o miejsce Wilna w państwotwórczej ideologii litewskiego nacjonalizmu, odpowiedzi poszukałem w 32. tomie serii „Studien zur Ostmitteleuropaforschung" publikowanej przez Instytut Herdera w Marburgu. Napisana po angielsku książka jest wspólnym dziełem pracowników Instytutu Historii Litwy w Wilnie, Dangirasa Mačiulisa i Dariusa Staliūnasa. Obaj od lat zajmują się problematyką odradzania się państwowości litewskiej oraz, przede wszystkim, historią międzywojennej Litwy. Darius Staliūnas o miejscu Wilna w ideologii litewskiej pisał już wcześniej (Staliūnas, 2000). Jednak dopiero w publikacji napisanej wraz z Mačiulisem kwestie tam poruszone doczekały się pełnego rozwinięcia.

Książka choć datowana na rok 2015, w ręce czytelników trafiła, jak się to często zdarza, dopiero w roku kolejnym. Na 236 stronach obaj autorzy wyjaśniają „jakie argumenty determinowały to uporczywe pragnienie liderów litewskiego nacjonalizmu stworzenia narodowego państwa z Wilnem jako stolicą" (Mačiulis \& Staliūnas, 2015, s. 2). Ich głównym celem, jak zaznaczają (Mačiulis \& Staliūnas, 2015, s. 3), jest analiza, ewolucja i realizacja wśród mas idei Wilna, jako stolicy nowoczesnej Litwy, która była pielęgnowana w końcu XIX i w pierwszej połowie XX wieku.

Podkreślają (Mačiulis \& Staliūnas, 2015, s. 4), że do kategorii nacjonalizmu podchodzą bez pejoratywnych konotacji, rozumiejąc ją raczej jako społeczną aktywność mającą na celu wdrożenie projektu narodowego, tj. państwa narodowego obejmującego wszystkich rodaków.

Całość problematyki zostaje rozwinięta w pięciu rozdziałach i krótkim zakończeniu, będącym spojrzeniem na problem, wykraczającym poza chronologię książki, do okupacji sowieckiej oraz pierwszych lat powojennego Wilna.

Pierwszy rozdział, zatytułowany „Under the Rule of the Romanovs”, to próba odpowiedzi na pytania: dlaczego w końcowym okresie imperium rosyjskiego (w którego skład wchodziła wówczas Litwa) liderzy litewskiego nacjonalizmu zdecydowali, że to właśnie Wilno stać ma się centrum narodowej Litwy?; przed jakimi stanęli oni wówczas problemami?; i wreszcie, jak zamierzali wdrożyć tę ideę?

Początkowo, jak zauważają Mačiulis i Staliūnas (2015, s. 8), Wilno nie było najistotniejsze w ideologii liderów litewskiego ruchu narodowego, gdyż skupiali się oni przede wszystkim na kwestii unarodowienia chłopów. Dopiero w 1900 roku Jonas Biliūnas w proklamacji "Litwini i Litwinki” zdefiniował Wilno jako „prawdziwe serce Ojczyzny” (Mačiulis \& Staliūnas, 2015, s. 9). W dalszej części rozdziału pokazany jest spór o to, w którym mieście powinna zostać ulokowana stolica przyszłej Litwy: Wilnie czy Kownie.

Zastanawiając się nad tym, jak litewskiej inteligencji w końcu udało się wprowadzić ideę Wilna, jako przyszłej stolicy nowoczesnego państwa litewskiego, w świadomość masową, autorzy zauważają (Mačiulis \& Staliūnas, 2015, ss. 20-21), że znaczącą rolę w tym procesie odegrał Wielki Seimas Wileński i ukazanie się pierwszego dziennika w języku litewskim „Vilniaus žinios” („Nowości wileńskie”). Podkreślają, że idea Wilna jako sto- 
licy lub centrum religijnego dla Litwinów była wprowadzana w podręcznikach geografii, W opisach pielgrzymek, w dziełach sztuki i poezji. Zaznaczają (Mačiulis \& Staliūnas, 2015, s. 21), iż bardzo istotną rolę odegrał tu poemat Maironisa" "Vilno".

W dalszej części rozdziału szczegółowej analizie poddane zostały pozostałe przyczyny utrwalenia pozycji Wilna jako stolicy w świadomości zbiorowej Litwinów, a także w jaki sposób odnosili się do idei Wilna, jako stolicy Litwy, aktywiści białoruscy (Mačiulis \& Staliūnas, 2015, s. 38) oraz komuniści (s. 39). Nieco szerzej opisują stosunek Polaków (Mačiulis \& Staliūnas, 2015, s. 37) i zauważają, że politycy tacy jak Jonas Basanavičius i Antanas Smetona prowadzili negocjacje z rosyjską prawicą, aby stworzyć wspólny antypolski front (s. 44).

W drugim rozdziale litewscy historycy zajmują się tą samą problematyką w warunkach I wojny światowej. Na początku omawiają rolę uchodźców w zamianie krajobrazu narodowościowego miasta. Przytaczają litewską prasę, która wyrażała nadzieję, iż wzrost liczebności litewskich mieszkańców Wilna nie jest chwilowy i utrzyma się po wojnie (Mačiulis \& Staliūnas, 2015, s. 46). Jednak mimo faktu, iż nabożeństwa w języku litewskim zaczęły odbywać się w większej liczbie kościołów - jak zauważają autorzy - fala uchodźców zasadniczo nie zmieniła charakteru miasta - wciąż było ono miastem polskim (Mačiulis \& Staliūnas, 2015, s. 48).

W czasie I wojny światowej w Wilnie pojawił się nowy gracz, niemiecki rząd okupacyjny. Według Mačiulisa i Staliūnasa w latach 1915-1918 to właśnie Niemcy były aliantem litewskich aktywistów w realizacji fundamentalnego celu - niepodległego państwa litewskiego w jego etnograficznych granicach i z Wilnem jako stolicą (Mačiulis \& Staliūnas, 2015, ss. 50-53). 16 lutego 1918 roku ogłoszono niepodległość Litwy. Trzy dni później W "Lietuvos Aidas” ( „Echo Litwy”) podano, że niepodległe państwo litewskie ze stolicą w Wilnie zostało przywrócone (Mačiulis \& Staliūnas, 2015, s. 53).

Trzeci rozdział obejmuje okres od 1918 do 1923 roku i jest, jak podkreślają autorzy we wstępie, „poświęcony tradycyjnie rozumianej historii politycznej bardziej niż pozostałe części książki" (Mačiulis \& Staliūnas, 2015, s. 5). Rozpoczyna się od opisu utraty Wilna na rzecz bolszewików i utworzenia Litewsko-Białoruskiej Republiki Radzieckiej ze stolicą w Wilnie. Powołanie republiki dwunarodowej podyktowane było odgórnie z Moskwy i było narzuconym kompromisem, gdyż zarówno komuniści litewscy jak i białoruscy widzieli swoją stolicę w Wilnie (Mačiulis \& Staliūnas, 2015, s. 68). Dalej litewscy historycy opisują nieudane próby odzyskania miasta i zdobycie miasta przez Wojsko Polskie 22 kwietnia 1919 roku (Mačiulis \& Staliūnas, 2015, s. 71).

Następnie przedstawiają koncepcję Józefa Piłsudskiego stworzenia państwa federacyjnego Polski, Litwy i Białorusi. Odnoszą się również do koncepcji Romana Dmowskiego, co świadczy dobrej znajomości polskich antagonizmów z czasu budowy II RP (Mačiulis \& Staliūnas, 2015, s. 73). W dalszej części rozdziału przedstawiają polsko-litewską umowę, podpisaną w Suwałkach, na mocy której Wilno stawało się ponownie stolicą Litwy, tzw. "bunt Żeligowskiego" i inkorporację Wileńszczyzny do Polski.

W rozdziale czwartym, zatytułowanym "Jak wyzwolić stolicę? (1923-1939)", uwaga autorów skupiła się na problemie unaradawiania nacjonalizmu. Dla Mačiulisa i Staliūnasa najważniejsza jest odpowiedź na pytanie o to, jak litewskie elity polityczne zaszczepiły nacjonalistyczne idee wśród mas.

1 Maironis - właściwie Jonas Mačiulis (1862-1932), litewski poeta romantyczny, dramaturg, ksiądz katolicki i teolog. 
Na kolejnych kartach rozdziału zauważają, że utrata Wilna doprowadziła do upadku rządu Vytautasa Petrulisa w 1925 roku i zamachu stanu 17 grudnia 1926 roku, kiedy rozpoczęły się autorytarne rządy reżimu Antanasa Smetony. Opisują też atmosferę relacji litewsko-polskich, przypominając, że główny strateg polityki zagranicznej - premier Augustinas Voldemaras liczył na wsparcie Moskwy i Berlina w odzyskaniu Wilna, nie chciał natomiast nawet zasiadać do rozmów z Polakami, o ile nie byłyby one zgodne z aspiracjami Litwinów (Mačiulis \& Staliūnas, 2015, s. 97). Opisują też oficjalne zamrożenie stosunków dyplomatycznych, zaznaczając jednak, że tajne relacje dyplomatyczne w 1930 roku przeżywały swój najlepszy czas (Mačiulis \& Staliūnas, 2015, s. 99).

W dalszej części przedstawiona zostaje Unia Wyzwolenia Wilna - organizacja działająca w latach 1925-1938, której znaczenie w aktywnym zaszczepianiu idei Wilna jako serca Litwy w społeczeństwie litewskim, zostało szeroko opisane na kartach książki. W tym rozdziale przedstawione zostały również różnorakie formy rządowej propagandy, która wykreowała mit zniewolonego Wilna. Jak zauważają litewscy historycy, jeśli nie stworzono by mitu Wilna, to litewscy liderzy polityczni musieliby wymyślić inną ideę, która zjednoczyłaby społeczeństwo litewskie (Mačiulis \& Staliūnas, 2015, s. 125).

Ostatni rozdział koncentruje się na tym, jak litewskie elity polityczne, gdy otrzymały Wilno w prezencie od Stalina, starały się uczynić je miastem litewskim. Autorzy już na początku tej części książki dobitnie stwierdzają, że doskonale wiedziały one (tj. litewskie elity polityczne), że godząc się w zamian za Wilno na utworzenie sowieckiej bazy wojskowej (której kontyngent przewyższał liczebnie całą armię litewską), godzą się na prędką okupację kraju (Mačiulis \& Staliūnas, 2015, s. 173). Ponadto zauważają, że w międzywojennej Litwie władza cały wysiłek skupiała na zaszczepieniu w społeczeństwie idei Wilna jako stolicy. Jednak gdy przynależność tego miasta do Litwy stała się faktem, okazało się, że nie ma nawet wstępnego planu, co dalej robić (Mačiulis \& Staliūnas, 2015, s. 183).

Dla polskiego czytelnika ten rozdział jest ciekawy chociażby ze względu na opis traktowania przez rząd litewski zamieszkujących w Wilnie Polaków.

Podsumowując powyższe omówienie, można stwierdzić, że autorzy zrealizowali swój cel badawczy nie tylko poprzez analizę argumentów litewskich nacjonalistów, ale także biorąc pod uwage tradycje historyczne. Tym samym stanęli w opozycji do litewskich historyków konserwatywnych, którzy nie uznają istnienia problemu, uważając, że wraz z przebudzeniem narodowym wszyscy Litwini wiedzieli, ze Wilno było i powinno być stolicą Litwy. Obaj litewscy historycy, publikując tę książkę, wykazali się naukową odwagą i zastosowali swoisty wybieg. Wydając ją za granicą i w obcym języku, zminimalizowali ryzyko medialnego "linczu" ze strony krajowych oponentów.

Dangiras Mačiulis i Darius Staliūnas swe rozważania oparli na głębokiej kwerendzie archiwalnej nie tylko na Litwie, ale również w Archiwum Akt Nowych. Ponadto na szczególną uwagę zasługuje fakt, iż przygotowując publikację, przestudiowali roczniki aż 63 periodyków wydawanych po litewsku i po polsku. Bibliografia innych publikacji jest równie bogata.

W książce cytowane są również fragmenty pamiętników świadków opisywanych zdarzeń, co wzbogaca tekst. Przeczytać zatem możemy fragmenty wspomnień m.in. Mykolasa Römerisa, Zenonasa Ivinskisa czy Alfonsasa Nyka-Niliūnasa.

Dodatkowym plusem książki jest, często pomijane przez historyków, bogactwo ilustracji. Są to nie tylko fotografie aktorów ówczesnej sceny politycznej, ale gtównie plakaty 
propagandowe, karykatury z prasy oraz międzywojenne mapy z Wileńszczyzną jako terenem czasowo okupowanym przez Polskę.

Obowiązkiem wnikliwego recenzenta jest wynajdowanie błędów czy niedopatrzeń. Tych w książce trudno się doszukać. Jedynie na stronie 105 natrafiłem na błąd w zapisie polskiego określenia „Kowienczyzna” (chodzi oczywiście o Kowieńszczyznę) oraz na 107 literówkę w angielskim słowie "guarantour".

Szkoda, że autorzy poświęcili tak niewiele miejsca królowi Mendogowi II, który wstąpił na krótko na tron Litwy w 1918 roku. Koncepcja nowego królestwa litewskiego jest słabo opisana w historiografii i jej prezentacja byłaby z pewnością ciekawa dla czytelnika.

Nie zmienia to faktu, iż książkę uznać można za cenną. Zdaniem autora niniejszych słów powinna ona trafić do biblioteki każdego, kto zajmuje się historią Europy ŚrodkowoWschodniej, a dziejami dwudziestowiecznej Litwy i Polski w szczególności.

\section{BIBLIOGRAFIA}

Mačiulis, D., \& Staliūnas, D. (2015). Lithuanian nationalism and the Vilnius question 18831940. Marburg: Verlag Herder-Institut. (Studien zur Ostmitteleuropaforschung, 32).

Staliūnas, D. (2000). Wilno czy Kowno? Problem centrum narodowego Litwinów na początku XX w. W B. Linek \& K. Struve (Red.), Nacjonalizm a tożsamość narodowa w Europie Środkowo-Wschodniej w XIX i XX w. (ss. 259-268). Opole: Instytut Śląski. 